\title{
CJEM
}

Vol. 15, No. 4

July 2013 / juillet 2013

cjem-online.ca

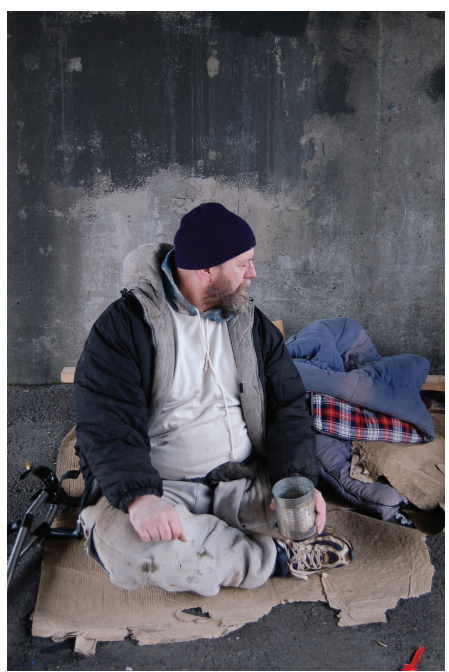

About the Cover:

Caring for frequent ED users is a challenging aspect of the practice of emergency medicine. This issue includes a study that defines and characterizes adult frequent users of a suburban Canadian ED.

\section{Table of Contents • Table des matières}

\section{EDITORIAL/COMIMENTARY • EDITORIAL}

191 Access to emergency care in rural Canada: should we be concerned? Richard Fleet, Patrick Archambault, Jeff Plant, Julien Poitras

194 L'accès aux soins d'urgence en milieu rural au Canada: y a-t-il lieu de s'inquiéter?

Richard Fleet, Patrick Archambault, Jeff Plant, Julien Poitras

\section{LETTERS • CORRESPONDANCE}

197 Impaired Driving Charges in Injured Impaired Drivers Requiring Emergency Department Treatment

John M. Tallon

\section{ORIGINAL RESEARCH・RECHERCHE ORIGINALE}

\section{ED Administration}

198 Influenza assessment centres: a case study of pandemic preparedness to alleviate excess emergency department volume

Geoffrey G. Hall, Alexander G. Perry, Adam vanDijk, Kieran M. Moore

EMS

206 Transport outcomes and dispatch determinants in a paramedic longterm care program: a pilot study

Jan L. Jensen, Andrew H. Travers, Darrell J. Bardua, Thomas Dobson, Bruce Cox, Jennifer McVey, Ed Cain, Robert Merchant, Alix J.E. Carter

\section{ED Administration}

214 Defining, quantifying, and characterizing adult frequent users of a suburban Canadian emergency department Jessica Moe, Allan L. Bailey, Ryan Oland, Linda Levesque, Heather Murray

\section{EM Advances}

227 Reliability of the Canadian Triage and Acuity Scale: interrater and intrarater agreement from a community and an academic emergency department Christopher M.B. Fernandes, Shelley McLeod, Joel Krause, Amit Shah, Justine Jewell, Barbara Smith, Lorraine Rollins

$C J E M \cdot J C M U$

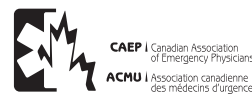

DECKER 


\section{BRIEF EDUCATIONAL REPORT • BREF COMPTE}

233 Implementation and evaluation of a novel research education rotation for Royal College of Physicians and Surgeons emergency medicine residents

Riyad B. Abu-Laban, Sandra Jarvis-Selinger, Lana Newton, Brian Chung

\section{KNOWLEDGE TO PRACTICE • DES \\ CONNAISSANCES À LA PRATIQUE}

Images

237 A lucky car accident

Thomas Nguyen, Marie-Luce Chirade, Apostolos

C. Agrafiotis, George El Khoury, Benjamin

Tatete, Marjorie Beumier, Jean-Louis Vincent

\section{Diagnostic Challenge}

239 An unusual cause of gum pain

Hans Rosenberg, Harold Rosenberg

\section{AdVERTISERS' INDEX INDEX DES ANNONCEURS}

Alberta Health Services

A7, A9

Allerject

A4, A5, A11, A12

Brockville General Hospital

A8

Canadian Association of Emergency Physicians

C2, C3, A6, A8, A10

Collingwood General Marine Hospital

A9

EMD Serono, Canada

A13-A16, C4

MEP Emergency Docs

A8

Queen's University

A9

St. Mary's General Hospital

A9

\section{EDUCATION • ENSEIGNEMENT}

241 Emergency medicine procedural skills: what are residents missing?

Andrew Petrosoniak, Jodi Herold, Karen

Woolfrey

\section{CASE REPORT • RAPPORT DE CAS}

249 Metabolic acidosis in toluene sniffing Jon Tuchscherer, Habib Rehman

\section{HUMOUR AND HUMANITY • HUMOUR ET HUMANITÉ}

253 The man who never was-redux Ron Leslie, George Kovacs

\section{Correction Notice}

CAEP and the Research Committee acknowledge Shelley L. McLeod, MSc and her contribution to research published in the May/June Abstract Supplement. Her name was omitted from the Author Index however, she is respectfully associated with the following abstracts: MP20, MP21, MP23, MP34, MP35, MP37, MP43, MP47, MP52, OP07, P24, P49, P51, P52, P53, P67, P79, P84, PL04.

Our sincerest apologies to Ms. McLeod. 
CAEP I Canadian Association of Emergency Physicians

ACMU I Association canadienne
des médecins d'urgence

President / Président

Bruce McLeod, MD

Canadian Journal of Emergency Medicine

Fournal canadien de la médecine d'urgence

\section{Editor-IN-Chief / RÉdActeUR en Chef}

James Ducharme, MD

McMaster University, Hamilton, Ont.

\section{Senior Associate Editors / Rédacteurs adjoint}

Riyad B. Abu-Laban, MD, MHSc

University of British Columbia, Vancouver, BC

Laurie J. Morrison, MD, MSc

University of Toronto, Toronto, Ont.

Brian Rowe, MD, MSc

University of Alberta, Edmonton, Alta.

Marco L.A. Sivilotti, MD, MSc

Queen's University, Kingston, Ont.

MANAging Editor / RÉdACtrice adMinistrative

Andrea Schaffeler, BA, BJourn

Pickering, Ont.

Assistant Managing Editor / Adjointe Á la rédactrice administrative Jennifer D. Artz, PhD

\section{EDITOR EMERITUS / RÉDACTEUR ÉMÉRITE}

Grant Innes, $M D$

University of Calgary, Calgary, Alta.

\section{AsSOciate Editors / RÉdActeURS ASSOcIÉs}

EM AdVANCES

Jacques S. Lee, MD, University of Toronto, Toronto, Ont.

Heather Murray, MD, MSc, Queen's University, Kingston, Ont.

Ian G. Stiell, MD, MSc, University of Ottawa, Ottawa, Ont.

CJEM JOURNAL CLUB

Michael J. Bullard, MD, University of Alberta, Edmonton, Alta.

Eddy S. Lang, MD CM, University of Calgary, Calgary, Alta.

COMmunity EM

David Mann, MD, Powell River General Hospital, Powell River, BC

Diagnostic Challenge

Brian Steinhart, MD, St. Michael's Hospital, Toronto, Ont.

ED AdMINISTRATION

Christopher M.B. Fernandes, MD, University of Western Ontario,

London, Ont.

Marc Afilalo, MD, McGill University, Montréal, Que.

Editorials/Radical Departure

Jeffrey Freeman, MD, University of Michigan, Ann Arbor, Mich.
EDUCATION

Jonathan Sherbino, MD, MEd, St. Joseph's Hospital, Hamilton, Ont.

HUMOUR AND HUMANITY

Jeffrey Freeman, MD, University of Michigan, Ann Arbor, Mich.

INTERNATIONAL EM

Garth Dickinson, MD, University of Ottawa, Ottawa, Ont.

Methodology: The Science of EM

Andrew Worster, MD, MSc, McMaster University, Hamilton, Ont.

Pediatric EM

Ran Goldman, MD, University of British Columbia, Vancouver, BC

Niranjan Kissoon, MD, University of British Columbia, Vancouver, BC

Michael Witt, MD, MPH, New Hampshire's Hospital for Children, Manchester, $\mathrm{NH}$

PHARMACOTHERAP

Peter J. Zed, BSc(Pharm), PharmD, University of British Columbia,

Vancouver, BC

Jeff Eppler, MD, Kelowna General Hospital, Kelowna, BC

Residents' CoRner

Catherine Patocka, MD, McGill University, Montreal, Que.

STATE OF THE ART

Vacant

TOXICOLOGY

Roy Purssell, MD, University of British Columbia, Vancouver, BC

\section{Editors at LARGe / RÉdActeurs Occasionnels}

Stephen Choi, MD, The Ottawa Hospital, Ottawa, Ont.

Robert S. Green, MD, Dalhousie University, Halifax, NS

Shane Neilson, BSc, MD, Guelph, Ont.

James Maskalyk, MD, St. Michael's Hospital, Toronto, Ont

Andrew McRae, MD, PhD, University of Calgary, Calgary, Alberta

Jeffrey Perry, MD, MSc, University of Ottawa, Ottawa, Ont.

Michael J. Schull, MD, MSc, Toronto, Ont.

Andrew H. Travers, BSc, MD, MSc (Epidemiol), Halifax, NS

Suneel Upadhye, MD, Hamilton, Ont.

\section{TransLation / Traduction}

Les Traductions Corpus

\section{EDITORIAL INQUiRIES}

Send to CFEM, c/o Andrea Schaffeler, Managing Editor, Canadian Fournal of Emergency Medicine, 628 Cowan Circle, Pickering ON L1W 3K7; cjem@rogers.com

\section{SUBMISSIONS}

Submissions to CFEM should be made at http://mc.manuscriptcentral.com/ cjem.

\section{SUBSCRIPTIONS AND ALL OTHER CORRESPONDENCE}

CFEM is owned by the Canadian Association of Emergency Physicians

(CAEP) and printed by General Printers, on acid-free stock.

CAEP Head Office: 1785 Alta Vista Dr., Ste. 104, Ottawa ON K1G 3Y6; tel 613 523-3343; fax 613 523-0190; admin@caep.ca

Address changes: contact customercare@deckerpublishing.com. Requests for permission to reproduce items in CFEM: contact permissions@ deckerpublishing.com

\section{PUblisher / Éditeur}

CFEM is owned by the Canadian Association of Emergency Physicians (CAEP). CFEM is published in January, March, May, July, September and November for CAEP by Decker Intellectual Properties. CAEP and Decker Intellectual Properties assume no responsibility or liability for damages arising from any error or omission, or from the use of any information or advice contained in the journal, including articles, editorials, case reports, reviews, media reviews, letters and advertisements. All editorial matter in
CFEM represents the opinions of the authors and not necessarily those of CAEP, the publisher, its subsidiaries and their respective directors.

\section{Journals Manager}

Paula Mucci

Advertising / Annonces

John D. Birkby

jbirkby@andrewjohnpublishing.com 


\section{A VOlCE,}

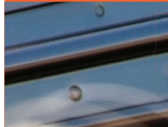

WHEN IYOURS

\section{CANT BE THIER

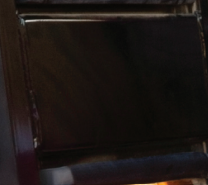

(Approximate size)

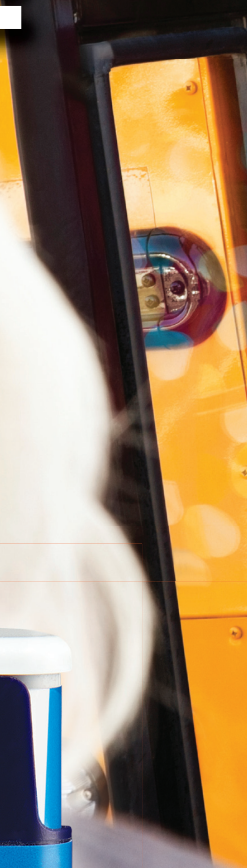

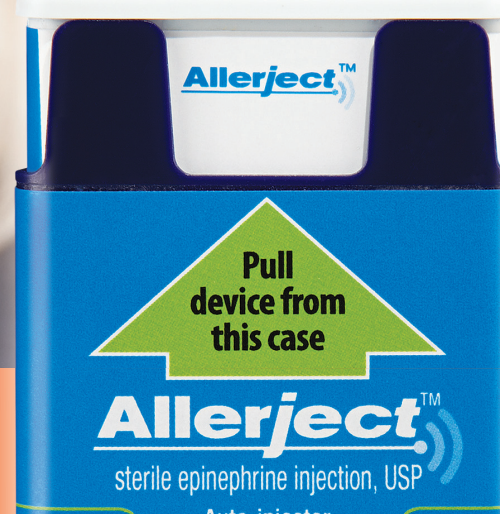

Auto-injector

FOR ALLERGIC EMERGENCIES

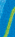

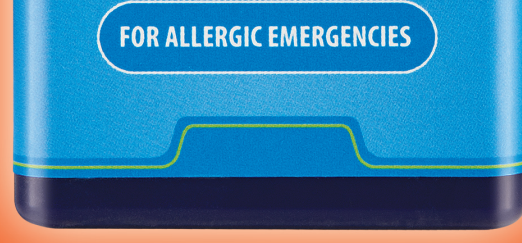
. $=\infty$

New in epinephrine auto-injectors!

It Talks! The first and only epinephrine injector with audio instructions*

Easy-Use Design! ALLERJECT ${ }^{T M}$ was designed to be easy to use

Compact! Fits in your palm...designed for portability

Lights-Up! LED flashes when injection is complete

Living with the risk of anaphylaxis...

We'll talk you through it! Aل 
INDICATIONS

ALLERJECT ${ }^{\mathrm{TM}} 0.3 \mathrm{mg}(0.3 \mathrm{~mL}$ Epinephrine Injection, USP, 1:1000) and ALLERJECT ${ }^{\mathrm{TM}} 0.15 \mathrm{mg}(0.15 \mathrm{~mL}$ Epinephrine Injection, USP, 1:1000) are indicated for the emergency treatment of anaphylactic reactions in patients who are determined to be at increased risk for anaphylaxis, including individuals with a history of anaphylactic reactions. Selection of the appropriate dosage strength is determined according to patient body weight. ALLERJECTTM is intended for immediate self-administration for the emergency treatment of severe allergic reactions (Type I).

\section{CONTRAINDICATIONS}

There are no absolute contraindications

to the use of epinephrine in a lifethreatening allergic situation.

WARNINGS AND PRECAUTIONS As a precaution, epinephrine use should be avoided in patients with: cardiogenic, traumatic, or hemorrhagic shock; cardiac dilation; and/or cerebral arteriosclerosis; organic brain damage; narrow-angle glaucoma. Caution should be applied when administering to elderly or hyperthyroid individuals, pregnant women, and individuals with cardiovascular disease or diabetes.

General: Patients with a history of anaphylaxis are at risk for subsequent episodes and even death. All patients who have had one or more episodes of anaphylaxis should have injectable epinephrine with them or with their parent or caregiver at all times, and should wear some form of medical identification bracelet or necklace. Epinephrine injection is not intended as a substitute for medical attention or hospital care. In conjunction with the administration of epinephrine, the patient should seek appropriate medical care.

Comparative clinical significance unknown.

Please see Product Monograph for complete warnings, precautions, adverse events and dosing information. Product Monograph available upon request or at www.sanofi.ca

For more information: 1-855-405-4321

Consumer website: www.allerject.ca

Manufactured for sanofi-aventis Canada Inc., Laval, Quebec.

Canada H7V OA3

\section{SANOFI

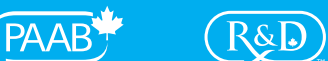

See prescribing summary on page A11

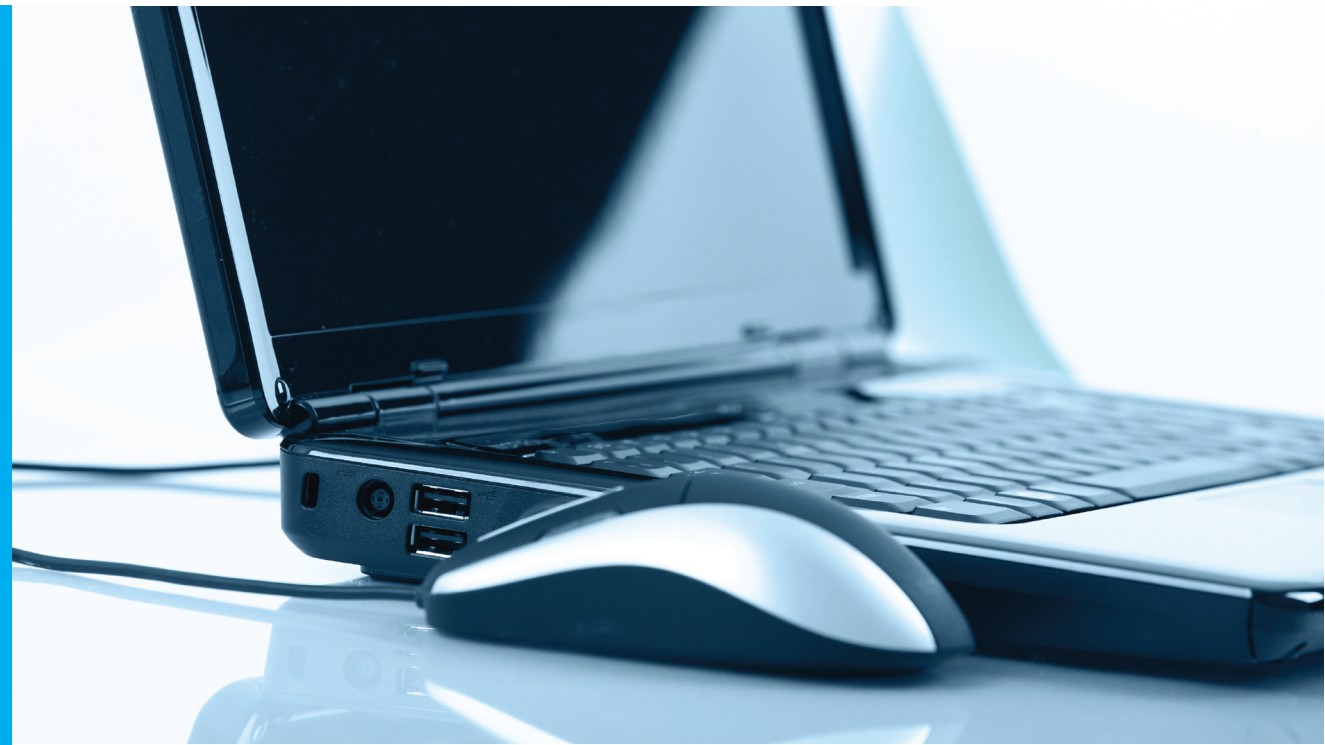

Journal authors!

Submit your manuscripts online to

Canadian Journal of Emergency Medicine at http://mc.manuscriptcentral.com/cjem.

Speeds up and simplifies the publishing process.

Keeps you informed from submission to acceptance.

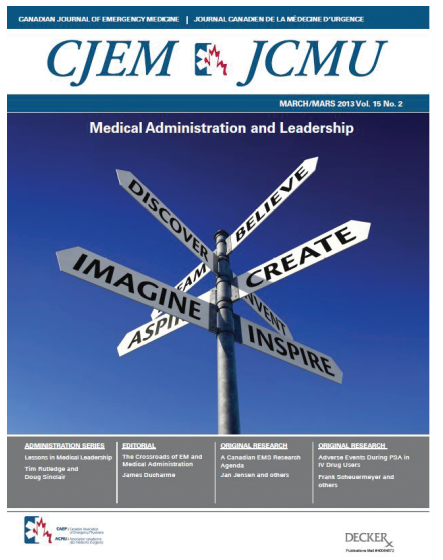

Submit your manuscripts on Manuscript Central. It's the online tool that makes submission easy and expedites the peer review process. You can even track the progress of your manuscript through to acceptance.

THOMSON

\section{SCHOLARONE ${ }^{\oplus}$} MANUSCRIPT CENTRAL TM

Manuscript Central ScholarOne are registered trademarks of Thomson Scientific.

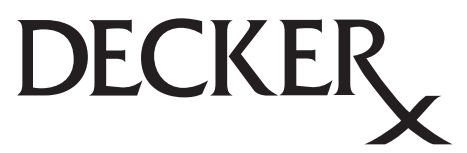

www.deckerpublishing.com 

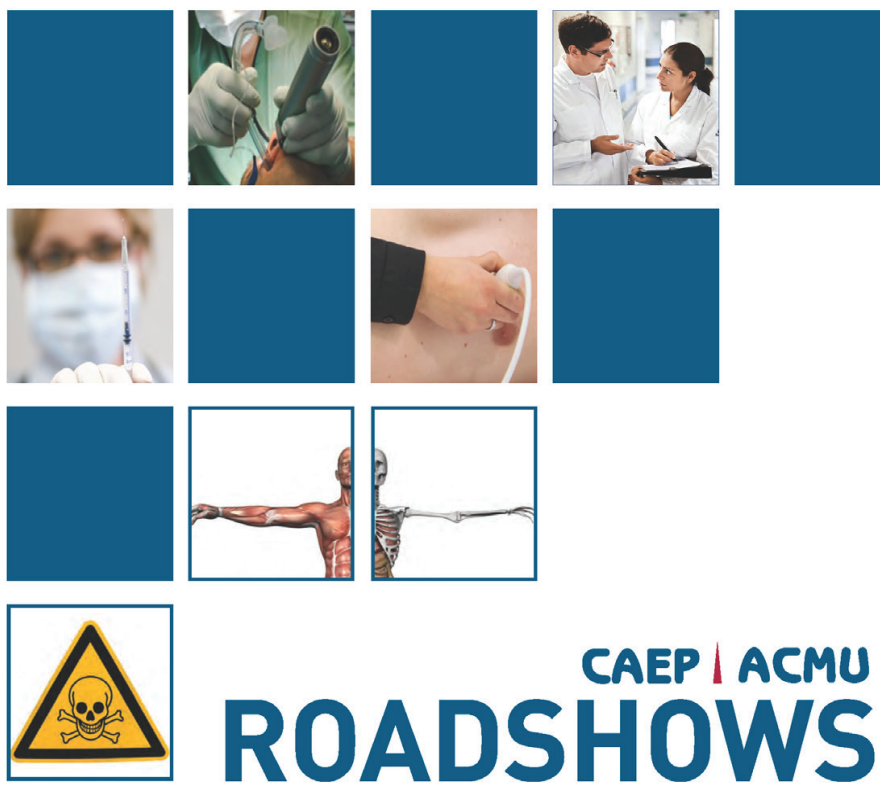

CAEP I ACMU

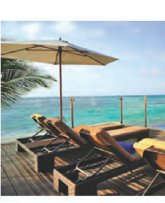

CME That Travels

2013 CME Roadshow Catalogue
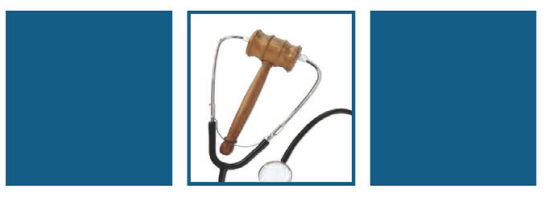

Proudly presented by

Nh/
The 2014 CAEP CME Roadshow

Catalogue is coming!

Order copies of the CAEP CME Catalogue for you and/or your hospital. Just fill out the order form below and when the 2014 CAEP CME Catalogue is released, we will ship your order directly to you.

Please return completed forms via e-mail to Lee Arbonatlarbon@caep.ca or fax 613.523.0190.

\section{CAEP CME Catalogue Order Form}

Name:

Address:

City: Prov: Postal Code:

Email:

SHIPPING ADDRESS: (if different then above)

Address:

City: Prov: Postal Code:

How many copies of the 2014 CME Catalogue do you wish to order:

$10 \square 20 \square 30 \square 40 \square 50 \square$ Other $\square$ Please specify quantity: 